\title{
RELACJA MIEOŚCI BOGA DO MIŁOŚCI BLIŹNIEGO W TRADYCJI BIBLIJNEJ
}

\section{(Próba syntezy)}

Tematem niniejszego artykułu jest próba syntetycznego spojrzenia na relację, jaka zachodzi w Piśmie św. i związanej z nim literaturze judaistycznej, między przykazaniem miłości Boga a przykazaniem miłości bliźniego. Tak ujęty temat - godny właściwie większego studium monograficznego - dyktuje nam metodę: jest to selekcja tradycji biblijnych (Traditionsgeschichte), które przyczyniły się wydatnie do ewolucji zagadnienia. Będzie to więc próba syntezy, a każda synteza niesie ze sobą ryzyko uogólnienia. Fakt, że dylemat: miłość Boga czy miłość ludzi — jest dziś aktualny w chrześcijaństwie ${ }^{1}$, niewątpliwie przyczynił się do zajęcia się tym zagadnieniem.

1 „W środowiskach, które uważają się za religijne i chrześcijańskie, spotykamy się ze zjawiskiem religii antropocentrycznej, to znaczy skierowanej ku człowiekowi jako głównemu punktowi zainteresowania, podczas gdy religia winna być z natury swej teocentryczna, to znaczy zwrócona ku Bogu jako swemu początkowi i pierwszemu celowi, a potem ku człowiekowi... Mówi się o religii pionowej i o religii poziomej. Ta druga przeważa dziś u tych, którzy nie mają perspektywy ontologicznej, to znaczy prawdziwej i obiektywnej religii... Ale powinniśmy mieć zawsze na uwadze, że miłość bliźniego jest również miłością Boga." (Papież $\mathrm{Pa}-$ weł VI w przemówieniu z 10 lipca 1968 r.; cyt. za „Osserv. Rom.”). Kard. J. Daniélou pisze o niebezpieczeństwie horyzontalizmu, który „ogranicza się do sprowadzenia chrześcijaństwa do wymiarów miłości bliźniego. Początki takiej dążności są łatwe do odgadnięcia. Dążność taka wypływa z faktu, że w moralnej chrześcijańskiej akcent został położony zbyt jednostronnie na obowiązki religijne, podczas gdy obowiązek społeczny chrześcijan został może niedostatecznie uwzględniony. Lecz na skutek gwałtownej reakcji horyzontalizm zdąża do umniejszenia wymiaru wertykalnego stosunku do Boga, kultu, modlitwy, w celu sprowadzenia chrześcijaństwa do wymiaru służby społecznej. Jest rzeczą nade wszystko pewną, że w chrześcijaństwie miłość do Boga jest takim samym wymiarem zasadniczym jak miłość bliźniego... Horyzontalizm jest wyrazem kryzysu odczucia Boga w łonie chrześcijaństwa.” (Sull' „orizzontalismo”, „Osserv. Rom.”, z 3 paźdz. 1968). 


\section{I - STARY TESTAMENT}

Stwierdzając obecność tekstów mówiących o przykazaniu miłości Boga (zob. Pwt 6, 5; Wj 20, 6; Sdz 5, 31; Jr 2, 2) i o przekazaniu miłości bliźniego (zob. Kpł 19, 17 n; Mi 6, 8), musimy równocześnie zauważyć, że Stary Testament nigdzie wyraźnie nie zbliża tych dwu przykazań do siebie. Niemniej jednak można spostrzec pewne dane przygotowujące formalną asocjację dwu miłości w Nowym Testamencie.

1. Jeżeli chodzi o semantykę, czasownik ’âhab oznacza miłość Boga i miłość ludzką w rozmaitych formach ${ }^{2}$. Takie ujęcie występuje w tradycji deuteronomicznej (por. Pwt passim; Joz 22, 5; 23, 11). Doszło nawet do tego - jak zauważył W. L. Moran - że 'âhab - „kochać" jest zamieniane niejednokrotnie z 'âbab — „służyć” 3. Obowiązek miłości Boga pociąga za sobą obowiązek służenia $\mathrm{Mu}$, co dokonuje się przy wypełnianiu zobowiązań międzyludzkich (zob. Pwt 22, 1-4; 24, 6n).

Pod względem struktury literackiej jest rzeczą charakterystyczną, że teksty deuteronomiczne mówiące o miłości Boga łączą się z tekstami na temat Przymierza ${ }^{4}$. O. Procksch - wychodząc z pojęcia Przymierza sądził, że w Deuteronomium, a zwłaszcza w jego części poświęconej prawu apodyktycznemu, nastąpiło zbliżenie dwu przykazań miłości ${ }^{\mathbf{5}}$. Inni egzegeci jednak — wymieńmy tylko W. Eichrodta i G. von Rada wypowiadają się na ten temat bardziej umiarkowanie ${ }^{6}$. Bez wątpienia, miłość dla Jahwe - tak jak przedstawia to Pwt - polega na kroczeniu drogami Jahwe, na służeniu $\mathrm{Mu}$, na przestrzeganiu Jego przykazań ${ }^{7}$. Tak więc pojęcie miłości Boga w Pwt jest pojęciem „miłości Przymierza” 8 .

Nie ulega kwestii, że debatę $\mathrm{w}$ tej dziedzinie rozpoczął anglikański biskup J. A. T. Robinson, wydając swą głośną pracę Honest to God, Londyn 1963 (pol. tłum. w: Spór o uczciwość wobec Boga, Bibl. Więzi, t. XVII, W-wa 1966, zob. ss. $85 \mathrm{nn}$.). Na gruncie biblijnym dobrą odpowiedź Robinsonowi dał Coppens J., La doctrine biblique sur l'amour de Dieu et du prochain," Ephem. Theol. Lovan.", 40 (1964) 252-299.

2 Zob. Brown F.- Driver S. R.- Briggs C. A., Hebrew and English Lexicon of the Old Testament, Oxford 1966, $12 \mathrm{n}$. Thomas W., The root aheb "love" in Hebrew, "Zeitschrift für die Alttest. Wissen.", 16 (1939) 57-64. Wiéner Cl., Recherches sur l'amour pour Dieu dans l'A.T., Paryż 1957.

3 Moran W. L., The Ancient Near Eastern Background of the Love of God in Deuteronomy, „Cath. Bibl. Quart.", 25 (1963) 77-87. Autor porównuje Pwt 7 , 9 z $1 \mathrm{Krl} 8$, 23, gdzie redaktor deuteronomiczny zastępuje 'abadîm przez 'ôhabîm (tamże, nota 9).

$4 \mathrm{Na}$ temat struktury literackiej Pwt zob. Lohfink N., Das Hauptgebot. Eine Untersuchung literarischer Einleitungsfragen zu Dtn 5-11 (Anal. Biblica 20), Rzym 1963, 78.

5 Procksch O., Theologie des A. T., Gütersloh 1949, 239.

6 Eichrodt W., Theologie des A. T. 1, Göttingen 71962, $162 \mathrm{nn}$. Von Rad G., Theologie des A. T., I, München ${ }^{4} 1962,213-243$.

7 Zob. Moran, art. cyt., 78.

8 Snaith N. H., The distinctive Ideas of the Old Testament, Londyn ${ }^{3} 1947$, 94-142, rozróżnia między ,the Covenant-Love of God" i ,the Election-Love of God". Podobnie Moran pisze o „covenantal love” (art. cyt., 78). 
W tej perspektywie wypada - choćby marginesowo - postawić pytanie, czy doktryna deuteronomiczna dotycząca miłości obejmuje także miłość Boga ku ludziom. Otóż miłość Boga do ludzi wyraża się niewątpliwie w samym Przymierzu (zob. Pwt 7, 7-9) ${ }^{9}$. Miłość Boża jest źródłem wybrania Izraela. Jak to podkreślił J. Coppens, pojęcie prawa, przymierza było podstawowe w Izraelu tak, że Izraelici ujmowali pod tym kątem wszysttkie swoje stosunki z Bogiem, łącznie z miłością do Boga ${ }^{10}$.

Należy zanotować także tematy związane z pojęciem miłości Bożej. Chodzi tu głównie o asocjację tematyczną: da'at 'Elohîm i hesed, która wyraża miłość wobec bliźniego, opartą na łaskawości Bożej. Taką asocjację tematyczną spotykamy w nauczaniu prorockim. ${ }^{11}$

2. Pouczająca jest doktryna o miłości zawarta $\mathrm{w}$ tekstach $\mathrm{m}$ ą $\mathrm{dr}$ oś c i ow y c h. Zacznijmy od Mdr 3, 9: tekst ten bowiem jest charakterystyczny ze względu na paralelizm:

w. 9a: zaufali (Bogu)

w. $9 \mathrm{~b}$ : wierni

- zrozumieją prawdę

— w miłości

Miłość jest tutaj połączona ze zrozumieniem prawdy; wierni $\mathrm{w}$ tej miłości, którzy zaufali Bogu, znajdą łaskę i miłosierdzie (w. 9c).

W Syr wyrażenie ,bojący się Pana" (phoboúmenoi Kyrion) występuje często w paralelizmie z wyrażeniem „miłujący go" (agapôntes auton).12

Syr 2, 15-16:

„Bojący się Pana będą posłuszni Jego słowom,

a miłujący Go pójdą Jego drogami.

Bojący się Pana szukać będą Jego upodobania,

a miłujący Go znajdą nasycenie w Prawie".

Mamy tutaj do czynienia $z$ paralelizmem nie antytetycznym, lecz synonimicznym: miłość Boga przynależy do tej sfery religijnej, która oznacza bojaźń Bożą, a to pociąga za sobą obowiązek przestrzegania przykazań.

W Syr 34, 13-16 stosunek bojaźni do miłości jest przedstawiony dynamicznie; można to ująć schematycznie:

$$
\begin{aligned}
& \text { w. 13: bojaźń - nadzieja } \\
& \text { w. 14: bojaźń - nadzieja } \\
& \text { w. 15: bojaźń - podpora } \\
& \text { w. 16: miłość Boga }
\end{aligned}
$$

9 Zob. von Rad, dz. cyt., 236 n.

10 Art. cyt., 265. Zob. także Reymond Ph., L'amour de Dieu dans le don de la loi, „Verbum Caro", 14 (1960) 299-306.

11 Por. Oz 6, 4. 6; 12, 7; 10,12-13;4, 1; Mi 6, 8; Prz 2, 5. Septuaginta w większości wypadków tłumaczy hebr. hesed przez eleos.

12 Zob. Haspecker J., Gottesfurcht bei Jesus Sirach, (Anal. Biblica 30), Rzym $1967,281-312$. 
Z faktu, iż miłość występuje po bojaźni, można wnioskować o jakimś postępie, względnie nawet zakończeniu, pewnego procesu ewolucyjnego: chodzi tu o postawę człowieka wobec Boga, wyznaczoną już nie kryteriami bojaźni, lecz miłości.

Inny tekst Syr 7, 29-31 wyraźnie łączy — przy pomocy tematu spójnego bojaźni - miłości Boga i obowiązki wobec Jego sług ${ }^{13}$ :

$$
\begin{aligned}
& \text { w. 29: bojaźń Pana - cześć dla kapłanów }(\mathrm{a}-\mathrm{x}) \\
& \text { w. 30: miłość Boga }- \text { cześć dla kapłanów }(\mathrm{b}-\mathrm{x}) \\
& \text { w. 31: bojaźn Boga }- \text { cześć dla kapłanów }(\mathrm{a}-\mathrm{x})
\end{aligned}
$$

Zatrzymaliśmy się nieco dłużej nad niektórymi tekstami Syr, ale wydaje się, że te teksty sapiencnjalne odzwierciedlają ewolucję pojęcia miłości odbywającą się w mentalności judaistycznej. Pierwszy wniosek, jaki z analizy tych tekstów możemy wysnuć, to wrażenie, iż zachowanie przykazań Bożych jako wyraz miłości Boga obejmuje całego człowieka w jego stosunku do Boga. Miłość bliźniego, choć wyrosła z prawa (w rozumieniu biblijnym!), nie jest legalistyczna, lecz egzystencjalna; stąd wynika spotkanie się dwu miłości - Boga i bliźniego na płaszczyźnie zachowywania przykazań. Następnie zauważamy, że ważną rolę pośrednika zajmuje tutaj pojęcie mądrości - wszak jesteśmy na gruncie literatury sapiencjalnej. Otóż miłość Jahwe sprowadza mądrość, ukochanie zaś mądrości powoduje z kolei miłość Boga. Tekstem klasycznym na poparcie powyższego twierdzenia jest Syr 4, 14: „miłujących ją (mądrość) Pan będzie miłował". Jest to jak gdyby układ zamknięty miłości, który przygotowuje grunt pod koncepcję nowotestamentarną miłość, a zwłaszcza tę Janową, że Bóg jest źródłem miłości, która wyszedłszy od Niego, wraca doń poprzez ludzi z powrotem.

Zwróćmy jeszcze uwagę na opowiadanie Tb 14, 7, które nosi wszelkie znamiona struktury a pokaliptycznej: wszyscy synowie Izraela, którzy ocaleją w tych dniach, miłować będą Boga w prawdzie. Ta miłość zasadza się na czynieniu sprawiedliwości, jałmużnie i innych uczynków miłosierdzia względem bliźnich (w. 8 i 9).

\section{II - JUDAIZM PALESTYŃSKI I HELLENISTYCZNY}

1. Pisma z Qumran zawierają naukę o miłości Boga ${ }^{14}$ i o miłości wobec braci - członków społeczności ${ }^{15}$, lecz nigdy nie łączą tych dwu miłości ze sobą. Miłość bliźniego — „miłość łaskawa” (hesed) wchoEDS:

13 Coppens pisze o ,préoccupation cléricale de l'hagiographe” (art. cyt., 281, nota 108 ).

14 Zob. CD 19, 2; 20, $21 \mathrm{n}$.

15 Zob. CD 6, 20.

16 Zob. 1 QS 2, 24; 5, 4; 5, 25; 8, 2; 10, 26; CD 13, 18. 
dzi w skład listy cnót praktykowanych w społeczności ${ }^{16}$; ogranicza się ona jednak tylko do społeczności kumrańskiej: członkowie społeczności powinni kochać wszystkich synów światłości, a nienawidzieć wszystkich synów ciemności ${ }^{17}$. Literatura kumrańska zatem pod względem asocjacji przykazań miłości nie tylko nie rozwija tradycji biblijnych, ale wyraźnie znajduje się w tyle; wynika to chyba ze specyfiki społeczności w Qumran.

2. W Testamentach Dwunastu Patriarchów zachęty do praktykowania miłości Boga i bliźniego zajmują poczesne miejsce. Co więcej - obserwujemy tam ścisłe połączenie dwu przykazań: przykazanie miłości Boga jest nierozerwalnie związane z przykazaniami miłości bliźniego. Formuła charakterystyczna, przejawiająca się raz po raz, to „miłować się nawzajem" (agapân allêlous). Zauważmy jednak, że pojęcie miłości w Test XII jest związane jeszcze $\mathrm{z}$ pojęciem bojaźni Bożej ${ }^{18}$. Dawno już egzegeci wskazali na uderzające paralelizmy Test XII z Nowym Testamentem. Co do pochodzenia Test XII toczy się jeszcze spór, na którego rychle rozstrzygnięcie wcale się nie zanosi. Zwolennicy teorii interpolacji i zwolennicy teorii początków chrześcijańskich wysuwają argumenty al pari ${ }^{19}$. Jakkolwiek by jednak nie było - musimy się zgodzić na to, że Test XII są jednym $z$ bardzo ważnych świadectw na stosowanie pojęcia miłości w literaturze pozabiblijnej i doskonale odzwierciedlają teologię epoki, w której powstawały ${ }^{20}$.

3. Jeżeli chodzi o literaturę ta $\mathrm{rgumi}$ c zną i rabininis ty c zn ą, można zacytować Sifra Lev 19, 18, która przytacza dyskusję między R. Akibą a Ben Azzayem ${ }^{21}$. Otóż dla tego ostatniego (żyje ok. 110 po Chr.) miłość bliźniego polega ostatecznie na miłości Boga, od której nie da się oddzielić. Przy analizie literatury rabinistycznej należy pamiętać o złożoności zagadnienia. $\mathrm{Z}$ jednej strony bowiem istnieje szereg tekstów, które łączą obowiązek miłości bliźniego z obowiązkami wobec Boga, nie wspominając wcale o miłości Boga: do tych tekstów należy zaliczyć np.

171 QS 1, 9-10. Por. także 1 QS 1, 3-4; CD 8, 17-19, 30.

18 Zob. Test. Iss. 5, 2; 7, 6; Test. Dan 5, 3; Test. Ben. 3, 3; Test. Gaid 4, 2. Por. również Test. Rub. 6, 9; Test. Jud. 18, 3; Test. Zob. 5, 3; Test. Gad 6, 1. Tekst grecki Test. XII wydał ostatnio w oparciu o rękopisy z Cambridge M. de Jonge, Testamenta XII Patriarcharum (Pseudepigrapha V. T. Graece, I), Leiden 1964.

19 Nie wchodzimy tutaj w szczegóły dyskusji o pochodzeniu tego apokryfu. Jedni bowiem, jak A. Dupont-Sommer, A. Jaubert, M. Philonenko, opowiadają się za starą teorią interpolacji chrześcijańskiej apokryfu, drudzy natomiast, jak M. de Jonge, J. T. Milik, przyjmują wręcz jego chrześcijańskie autorstwo. Zob. Milik, J. T., Dziesięć lat odkryć na pustyni Judzkiej, W-wa 1968, 33-34.

20 Zob. Braun F.-M., Les Testaments des XII Patriarches et le problème le leur origine, „Revue Bibl.”, 67 (1960) 516-549. Zob. również wnioski metodyczne, jakie wysnuł w tej sprawie Spicq C., Agapè. Prolégomènes à une étude de théologie néo-testamentaire (Studia Hellenist. 10), Leiden 1955, 138.

21 Zob. Strack H. L.-Billerbeck P., Kommentar zum Neuen Testament aus Talmud und Midrasch, München 1961, I, 358. 
Sifre Dt 32, 29: „Co im mówi Tora? Przyjmijcie ciężar królestwa mojego imienia; niech jeden zachęca drugiego w bojaźni niebios i niech jeden prowadzi drugiego w uczynkach miłosierdzia" ${ }^{22}$. Z drugiej zaś strony liczne teksty dowodzą, że motorem prawdziwej miłości bliźniego jest miłość Boża: „Niech człowiek wypełni swe obowiązki względem bliźniego na tej samej zasadzie, jak wypełnia obowiązki wobec Boga" (J. Sheq. 47a). „Nie odmawiaj swej miłości nikomu, albowiem kto jej odmawia bliźniemu, jest podobnym bałwochwalcy” (Sifre Dt 98b). „Jeżeli jesteś miłosierny, Bóg miłosierny będzie miał litość nad tobą" (Tos. B. Q $9,30)$. „Jakie było największe przestępstwo pokolenia przed potopem? Że nie mieli litości nad bliźnimi. Dlatego Bóg również nie okazał litości wobec nich" (Gen Rabba 33, 6).

Dlatego też nie można już dzisiaj podtrzymywać opinii C. Spicqa, że ,,jednym z naczelnych braków teologii rabinistycznej jest słabe wypracowanie koncepcji miłości Boga i bliźniego" 23. Owszem, trzeba podkreślić, że teza „moralności ekskluzywnej”, ograniczającej miłość do kręgu mozaizmu, wysuwana przez doświadczonych egzegetów, jak Bertholet czy Bonsirven ${ }^{24}$, niejednokrotnie z racji apologetycznych: by wykazać różnice zasadnicze między chrześcijaństwem a judaizmem - jest niesłuszna i że jako taka została odrzucona przez poważnych autorów judaistycznych ${ }^{25}$. K. Hruby ${ }^{26}$ wyróżnia trzy etapy ewolucji problemu miłości $\mathrm{w}$ łonie judaizmu palestyńskiego:

- uniwersalizm początkowy, opierający się na objawieniu pierwotnym; „siedem przykazań Noego" (šeba miswot bene Noah) odegrało tutaj dużą rolę, także w późniejszym kształtowaniu się relacji judaizmu do chrześcijaństwa;

— ekskluzywizm, który można by nazwać „instrumentalnym”;

- perspektywa uniwersalistyczna jako wizja przyszłości i dopełnienie planu Bożego.

4. Spośród przedstawicieli judaizmu hellenistycznego należy wziąć pod uwagę Filona $\mathrm{z}$ Aleksandrii, który w swojej egzegezie

22 Zob. Bonsirven J., Textes rabbiniques des deux premiers siècles chrétiens, Rzym 1955, 83, nr 362. Por. także Spicq C., dz. cyt., 143 nn. Braun H., Spätjüdisch-häretischer und frühchristlicher Radikalismus, 2 tomy, Tübingen 1957, zwłaszcza t. II, gdzie autor wielokrotnie porusza problem dwu miłości w judaizmie.

23 Dz. cyt., 155.

24 Bertholet A., Die Stellung der Israeliten und Juden zu den Fremden. Fryburg $\mathrm{w}$ Br.-Lipsk 1896. Bonsirven J., Le Judaïsme palestinien au temps de Jésus-Christ, 2 tomy, Paryż 1934-35. Trzeba jednak sprawiedliwie przyznać, że obaj autorowie obiektywnie relacjonowali niuanse myśli judaistycznej w kwestii pojęcia miłości.

${ }_{25}$ Zob. Klausner J., Jesus von Nazareth. Sein Leben und seine Lehre, Jerusalem ${ }^{3} 1952$.

26 Hruby K., L'amour du prochain dans la pensée juive, „Nouvelle Revue Théol.", 91 (1969) 493-516. 
ksiąg świętych łączy ze sobą dwa przykazania miłości. Zacytujmy tekst chyba najbardziej charakterystyczny z De spec. leg. II, 63, w którym Filon mówi o dwóch zasadach: ,jedna zasada to obowiązek wobec Boga polegający na pobożności i świętości, a druga - to obowiązek wobec ludzi polegający na łaskawości-miłości (philanthrôpia) i sprawiedliwości" 72.

\section{III - NOWY TESTAMENT}

$\mathrm{W}$ analizie pism Nowe g o Test a mentu weźmiemy pod uwage synoptyków i pierwszy list św. Jana; pominiemy natomiast całe Corpus Paulinum, zostawiając je osobnemu studium.

1. Asocjację miłości braterskiej i miłości Boga wkładają s ynopt y c y w usta bądź samego Chrystusa (Mk 12, 28-34; Mt 22, 34-40) ${ }^{28}$, bądź uczonego w Prawie (Łk 10, 25-28). Zatrzymajmy się nieco nad tymi perykopami, charakteryzując pracę redakcyjną poszczególnego ewangelisty (Redaktionsgeschichte) w trosce o wydobycie właściwej każdemu z synoptyków koncepcji teologicznej.

Wynotujmy przy pomocy tabeli synoptycznej istotne elementy strukturalne perykop:

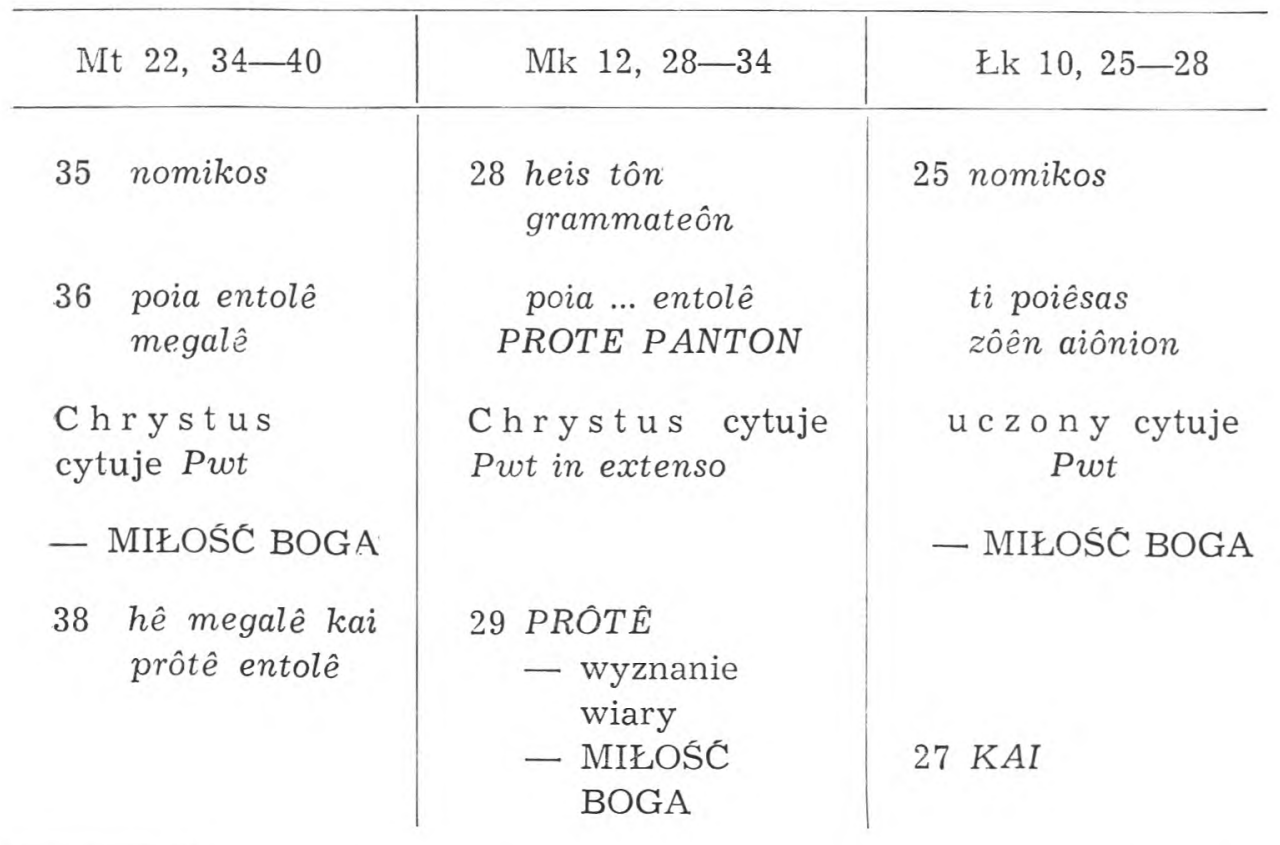

27 Według wyd. Cohn L.- Wendland P., Philonis Alexandrini opera quae supersunt, Berlin 1869-1930. 
39 deutera HOMOIA

- MIEOŚ́ BLIŹNIEGO

40 en tautais tais dysin entolais
31 DEUTERA

- MIEOŚC BLIŹNIEGO

meizôn TOUTONN allê ENTOLÊ

wzmianka o ofiarach
- MiŁośĆ BLIŹNIEGO

28 touto poiei

kai zêsê(i)

Przyjęło się już w kwestii synoptycznej poszukiwanie u $M k$ tradycji najstarszej. Tak też dzieje się i w naszym przypadku: M.-J. Lagrange sądził że właśnie $M k$ zachowuje cechy rzeczywistej rozmowy ${ }^{29}$; w logionie tym możemy usłyszeć ipsissimam vocem Chrystusa. Łk zaś przedstawia wersję młodszą, a $M t$ posługuje się terminem Eukaszowym: nomikos - „uczony w Prawie” $(22,35)^{30}$. Natomiast G. Bornkamm wyraża opinię przeciwną: według niego $M t$ i $£ k$ reprezentują tradycję najstarszą $^{31}$.

Zacznijmy od perykopy uważanej ogólnie za najstarszą - perykopy Markowej. Mk zawiera kilka wariantów godnych uwagi: tylko on daje pełny cytat $\mathrm{z}$ Pwt $6,4 \mathrm{n}$, a problem miłości umieszcza w ramach wyznania wiary monoteistycznej. Mk stawia wspólnie z $M t$ pytanie poia, które wydaje się mieć tutaj sens tis ${ }^{32}$. Charakterystyczne jest dalej zestawienie liczby pojedynczej entolê i mnogiej toutôn (w. 31), następnie rozróżnienie numeryczne pierwszego i drugiego przykazania (prôtê: w. 29 - deutera: w. 31), co niektórzy uważają za późniejszą warstwę

28 Spośród•komentarzy zob. Lagrange M. J., Evangile selon saint Marc, Paryż 1947. Taylor V., The Gospel according to St. Mark, Londyn 1953. Por. także studia monograficzne: Spicq C., Agapè dans le Nouveau Testament. Analyse des textes, 3 tomy, Paryż 1958-59, t. I, 36-46; 85-90; 137-148. Gils F., „Le sabbat a été fait pour l'homme et non l'homme pour le sabbat" (Mc II, 27), "Revue Bibl.", 69 (1962) 519-521. Montefiore H., Thou shalt love the Neighbour as Thyself, „Novum Test.", 5 (1962) 157-170. Grossouw W. K., Wat leert het Nieuwe Testament over de liefde tot God, "Tijdschrift voor Theologie”, 3 (1963) 230-251. Coppens J., art. cyt. 291.

29 Dz. cyt., 324. Podtrzymuje to zdanie Coppens, art. cyt., 291.

30 Zob. Légasse S., Scribes et disciples de Jésus, „Revue Bibli.”, 68 (1961) 481 n.

31 Bornkamm G., Das Doppelgebot der Liebe, w: Neutestamentliche Studien für R. Bultmann, Berlin 1954, 85-93. Autor mówi w sposób bliżej nieokreślony o Proto-Marku, piśmie wcześniejszym od drugiej ewangelii, którego istnienia nie potrafi jednak dowieść. Zob. jeszcze: Léon-Dufour X., Etudes d'Evangile, Paryż $1965,32$.

32 Takie jest zdanie większości egzegetów: zob. Swete H. B., The Gospel according to St. Mark, Londyn ${ }^{2} 1908$. Spicq tłumaczy poia przez "quelle sorte", "quelle catégorie" (Agapè, I, 45). Poios jest niemalże synonimem potapos, por. $1 \mathrm{~J} 3,1$. 
redakcyjną ${ }^{33}$. Pytanie uczonego w Prawie zakłada jedno przykazanie: „które przykazanie jest pierwsze ze wszystkich" (prôtê pantôn: w. 28). W perykopie Markowej chodzi więc o jedno przykazanie; pod względem struktury perykopa rozpoczyna się wyznaniem wiary, a kończy wzmianką o ofiarach, w czym można upatrywać reminiscencję mądrościową z Syr 7, 29-31 34. Przytaczając zaś początek Šema - zasadniczo niepotrzebny w kontekście zagadnienia największego przykazania - Mk zdradza się ze swą troską o dostosowanie przekazu ewangelicznego do pogan: w ke-rygmacie misyjnym wśród pogan taka wzmianka była jak najbardziej na miejscu ${ }^{35}$.

Tak więc perykopa Markowa, którą Spicq charakteryzuje jako „wzór teologii biblijnej" ${ }^{36}$, winna być rozpatrywana w kontekście sytuacji misyjnej powstającego Kościoła ${ }^{37}$.

$M t$ jest krótszy od $M k$, natomiast u obydwu jest ten sam kontekst. O ile jednak $M k$ akcentuje jedno przykazanie, to $M t$ mówi wyraźnie o dwóch - nie bez zaznaczenia zresztą ich podobieństwa (homoia: w. 39). Pragnie $\mathrm{w}$ ten sposób podkreślić, że cała moralność Nowego Przymierza zależy od tych dwu przykazań: „opiera się całe Prawo i Prorocy” (w. 40). Orientacja teologiczna perykopy Mateuszowej jest wyznaczona przez parenezę o królestwie niebieskim; Jezus kładzie główny akcent na miłość, a nie na sprawiedliwość ${ }^{38}$. Przykazanie miłości nie jest nałożone ludziom w ten sam sposób jak inne przykazania Prawa ${ }^{39}$.

Łk posiada warianty, które - zwłaszcza w porównaniu z poprzednimi perykopami - nie mogą nie zwrócić uwagi. Nowa orientacja teologiczna wpływa bez wątpienia na odmiennośc konstrukcji literackiej: perykopa o miłości bliźniego u $£ k$ jest wprowadzona jakby jakiś wstęp do przypowieści o dobrym Samarytaninie (ww. 29-37). Natomiast krótka perykopa poprzedzająca o szczęśliwej sytuacji uczniów Chrystusowych (ww. 23-24) przygotowuje jak gdyby psychologicznie do logionu o największym przykazaniu. Dwa przykazania są połączone ze sobą przy pomocy spójnika kai; następuje dalej pytanie o określenie bliźniego, na co odpowiedź jest rewelacją dla ówczesnych Żydów. Tym zaś, co nadaje całej perykopie Łukaszowej swoistej perspektywy teologicznej, sa for-

33 Zob. Coppens, art. cyt., 291, nota 128.

34 Zob. wyżej.

35 Zob. Gils, art. cyt., 520.

36 Agapè, I, 89, nota 3.

37 Zob. Léon-Dufour X., Les évangiles et l'histoire de Jeésus, Paryż 1963, $275-280 ; 306-311$.

38 W zaakcentowaniu miłości jeszcze dzisiaj żydzi ortodoksi widzą zasadniczą różnicę między chrześcijaństwem a judaizmem, por. Klausner, dz. cyt., 527.

39 Według R. Bultmanna, Die Geschichte der synoptischen Tradition, Göttingen 71967,57 , Mt przekształcił dyskusję szkolną (Schulgespräch) w spór istotny (Streitgespräch). 
muły: „czyń” i „osiągnąć życie wieczne”, które w całej strukturze perykopy tworzą jakby inkluzję (ww. 25 i 28) ${ }^{40}$. Pojęcie starotestamentowe czynienia przykazań nabiera w nakazie Chrystusa (ww. 28 i 37) nowego charakteru: przykazanie miłości winno być wypełniane w duchu Nowego Przymierza. To odpowiada dobrze teologii trzeciej ewangelii, która głosi miłosierdzie zbawcze ${ }^{41}$ : bliźnim jest ten, który "okazał miłosierdzie" (w. 37).

Wydaje się, że logion Chrystusowy o miłości bliźniego w redakcji Łk można by umieścić $\mathrm{w}$ kontekście katechetycznym: stopniowego nauczania uczniów Chrystusowych. W ten sposób można by dojść aż do społeczności przedpaschalne j ${ }^{42}$.

2. Listy J a nowe ze wszystkich pism Nowego Testamentu czynią najczęstszy użytek - w proporcji do swej objętości - z terminologii miłości: zawierają mianowicie 31 na 141 wzmianek czasownika agapan (czyli 22\% wszystkich wzmianek w NT) i 21 na 116 wzmianek rzeczownika agapê (czyli 18\%) ${ }^{43}$.

Zważywszy ten fakt, zbadajmy pokrótce tradycję Janową odnośnie relacji dwu miłości - Boga i bliźniego, tradycję, która najlepiej chyba odbiła się w jego pierwszym liście.44

Zestawienie formalne dwu miłości zachodzi w $1 J$ w sekcji 2, $29-$ 4, 6. Punktem wyjścia jest miłość okazywana nam przez Ojca, dzięki której jesteśmy w łączności z Nim $(3,1)$. Temat miłości braterskiej przejawia się $\mathrm{w}$ perykopie $3,11-22$; perykopa ta jest jak gdyby spięta dwoma terminami: aggelia (w. 11) i entolê (w. 22). Ten ostatni termin wskazuje na użycie przez Jana pojęcia przykazania jako elementu łączącego dwie miłości. Dla formalnego zespolenia dwóch przykazań w jedno autor wprowadza kilka tematów pokrewnych:

- Kain i brat jego $(3,12)$;

- serce i miłość Boga (17);

- miłowanie czynem i prawdą $(3,18)$.

40 O funkcji inkluzji (inclusion) zob. Vanhoye A., La structure littéraire de l'épître aux Hébreux (Studia Neotest. Studia 1), Paryż-Bruges 1963 1963, 37.

41 Zob. Conzelmann H., Die Mitte der Zeit, Studien zur Theologie des Lukas, Tübingen ${ }^{4} 1962,148 \mathrm{n}$.

42 Zob. uwagi Léon-Dufour, Les évangiles, $266 \mathrm{nn}$.

43 Zob. De Jonge M., "Geliefden, laten wij elkander liefhebben, want de liefde is uit God" (I Joh. 4:7), "Ned Theol. Tijdsch.", 22 (1968) 352-367.. Coppens J., Agapè et Agapân dans les Lettres johanniques, „Ephem. Theol. Lovan.”, 45 (1969) 45 (1969) $125-127$.

44 Zab. Chmiel J., Lumière et charité d'après la première épître de saint Jean, Rzym ( $w$ druku).

45 Zob. Bauer G. B., Il misfatto di Caino nel giudizio di S. Giovanni, „Rivista Bibl. Ital." 2 (1954) 325-328. O temacie Kaina w literaturze targumicznej pisze McNamara M., The New Testament and the Palestinian Targum to the Pentateuch (Anal. Biblica 27), Rzym 1966. 
Kain jest archetypem nienawiści tak, jak Abel, ,brat jego" - miłości ${ }^{45}$. W miejsce Abla wchodzi jednak w w. 16 On - ekeinos - Jezus Chrystus, który staje się nowym archetypem miłości braterskiej i którego winniśmy naśladować ${ }^{46}$. Jak trafnie zauważył Coppens, w St. T. miłość braterska wypływa z miłości Bożej za pośrednictwem idei naśladowania ${ }^{47}$. To przywodzi na pamięć opowiadanie Genesis o stworzeniu ( $\mathrm{Rdz}$ $1,26-27 ; 5,1)$. Z drugiej strony tekst Janowy podkreśla, iż jedynie przez Ofiarę Krzyża dochodzimy do tego, czym jest miłość $(3,16)$. Tak więc autor listu przybliża miłość braterską i miłość Bożą w perspektywie teologii stworzenia i zbawienia.

Mówiąc o ta splagchna: „wnętrzności-serce” (3, 17), Jan ma na myśli uczucie miłości i współczucia 48: chodzi o serce miłosierne wobec braci $\mathrm{w}$ potrzebie. Z tym miłosierdziem łączy się miłość Boża mieszkająca w nas. Zespół tematyczny: miłość Boża - serce miłosierne, poruszany $\mathrm{w}$ różnych aspektach $\mathrm{w}$ pismach nowotestamentowych ${ }^{49}$, nabiera w liście Jana teologicznej perspektywy. Najpierw miłość Boża napotyka na uczucie ludzkie, które jednak nie może mieć nic z kaprysu czy z mody, lecz ma wyrażać głęboką miłość, zakorzenioną w tej miłości, jaką Jezus Chrystus okazał nam, umierając na krzyżu.

Formuła w 3, 18: „miłować czynem i prawdą” łączy w sobie temat poprzednio występujący miłosierdzia uczynnego z tematem prawdy. Temat prawdy (alêtheia) u św. Jana należy do tematów Objawienia ${ }^{50}$. W 3, 19 Jan określa nasz stosunek egzystencjalny do Objawienia: ,jesteśmy z prawdy". Miłość bliźniego winna być aktywna, wyrażona czynem, lecz z drugiej strony nie może poprzestać na swym ludzkim aspekcie, chociażby najbardziej intensywnym. Miłość bliźniego musi czerpać z żywego źródła Objawienia Bożego, z prawdy, którą jest słowo objawione (aspekt teologiczny). Jeżeli nasza miłość jest prawdziwa, winna być darem siebie: „i my winniśmy oddać życie za braci” (3, 16b). Tutaj znów jest punkt, w którym miłość Boga przecina się z miłością bliźniego. Oddać życie - to nie zawsze stracić życie przez śmierć męczeńską, lecz

46 Por. J 15, 12-13; 13, 34-35. Bouttier M., La notion de frères chez saint Jean, „Revue d'Hist. Philosophie Rel.', 44 (1964) 190, zauważa, że milość braterska w $1 J$ ukazuje się jako imitatio Dei, ,mais précisément l'imitation d'un Dieu qui a envoyé son Fils non pour juger le monde, mais pour le sauver". Zob. także Weers A., Contribution à une recherche sur l'idée d'imitation dans les écrits johanniques (dysertacja na Fakult. Teol. w Lyonie, .1967).

47 Art. cyt., 283.

48 Tym terminem greckim Septuaginta tłumaczy hebr. rahamîm.

49 Por. Ef 4, 32; 1 P 3, 8.

50 $\mathrm{O}$ pojęciu prawdy u św. Jana zob. artykuły de la Potterie I., L'arrière-fond de la notion johannique de vérité, w: Studia Evangelica I, Berlin 1959, 277-294; La verità in San Giovanni, w: San Giovanni. Atti della XVII Sett. Biblica, Brescia 1964, 123-144; „Je suis la Voie, la Vérité et la Vie” (Jn 14, 6), „Nouvelle Revue Théol.", 98 (1966) $907-942$. 
także żyć w duchu, który ożywiał Pana, gdy oddawał za nas Swe życie ${ }^{51}$. Kochać - to oddać swe życie, czyli widzieć w bliźnim Chrystusa i Jemu służyć oddając Mu najlepsze ze swego (aspekt chrystocentryczny).

W 1 J 3, 23-24 dochodzi pojęcie przykazania, wielokrotnie już sygnalizowane w poprzednich wierszach; przykazanie łączy stylistycznie jako „słowo-spinacz" (mot-crochet) ${ }^{52}$ dwa pojęcia miłości. I oto mamy dwa obowiązki w jednym przykazaniu:

- wierzyć w imię Jezusa Chrystusa,

- miłować się wzajemnie.

Rozpoznać tu można wpływ tradycji mądrościowej; zachowywanie przykazań jest wyrazem miłości Boga ${ }^{53}$. Miłość Boga, poświadczona przez zachowywanie przykazań, łączy się z miłością ludzi - wiara chrystologiczna daje temu zespoleniu nowego charakteru.

W 1 J 4, 7-21 autor listu przedstawia relację miłości braterskiej do fundamentu miłości, jakim jest sam Bóg — „Bóg jest Miłością” (4, 8. 16): miłość braterska wiąże się $\mathrm{z}$ obecnością Boga $\mathrm{w}$ nas $(4,12.16)$. Punktem wyjścia będzie zawsze pierwsza i bezinteresowna miłość Boga ku nam $(4,19)$. W sekcji 5, 1-22 miłość Boża jest kryterium miłości bliźniego (w. 2).

Reasumując - św. Jan nie identyfikuje bez reszty miłości wobec Boga i miłości bliźniego; ustala tylko relację między nimi w sposób, który możemy bez przesady nazwać najradykalniejszym i najszczęśliwszym. Istota zespolenia miłości w koncepcji Jana polega na:

- podkreśleniu objawienia miłości Bożej dla człowieka; w tym sensie miłość Boga ma pierwszeństwo $\mathrm{w}$ stosunku do miłości bliźniego (4, 7-12. 19).

- Miłość bliźniego jest organicznie związana z miłością Boga, tak że miłość Boga i ludzi jest tej samej natury: jest to miłość objawiona $(4,21)$.

- Tylko miłując braci, możemy miłować Boga. W tym sensie można mówić o prymacie miłości bliźniego nad miłością Boga ${ }^{54}$.

W koncepcji teologicznej św. Jana miłość Boga i bliźniego stanowią jak gdyby system naczyń połączonych: miłość Boga pociąga za sobą miłość bliźniego i vice versa.

$*$

51 Por. Flp 2, 5.

52 O funkcji „mot-crochet” zob. Vanhoye, dz. cyt. 25, 37.

53 „Miłość zaś - to przestrzeganie jej (madrości) praw” (Mdr 6, 18).

54 "Dei dilectio prior est ordine praecipiendi; proximi autem dilectio prior est ordine faciendi". (Sw. Augustyn, In Io. Evang. XVII; PL 35, 1531). „Uno modo, ordine perfectionis et dignitatis: sicut dilectio Dei est prior dilectione proximi... Alio modo, ordine generationis seu dispositionis: sicut dilectio proximi praecedit dilectionem Dei, quantum ad actum." (Sw. Tomasz z Akwinu, Sum. Theol. I-II, q. 68, a. 8, ad 2). Zob. Féret H.-M., L'amour fraternel vécu en Église et le signe de la venue de Dieu, „Concilium”, 29 (1967) 19-36. 
Każda z tradycji biblijnych wniosła coś do ewolucji zagadnienia dwóch miłości. Najbardziej godne uwagi wydają się być: tradycja deuteronomiczna ze swą koncepcją przykazania miłości, wynikłą z idei Przymierza, oraz tradycja mądrościowa, która nawiązała do deuteronomicznej w pojęciu przykazania. Obie te tradycje wywarły piętno na myśli judaistycznej, można je spostrzec w N. Test. u synoptyków w logionie o największym przykazaniu. Lecz najbardziej uwidoczniły się $\mathrm{w}$ pierwszym liście św. Jana, który wypracował własną koncepcję teologiczną, mając stale na uwadze, że „Bóg jest Miłością” (1 J 4, 8. 16) ${ }^{55}$.

\section{R E S M}

\section{LE RAPPORT ENTRE L'AMOUR DE DIEU ET L'AMOUR DU PROCHAIN DANS LA TRADITION BIBLIQUE \\ (Ébauche d'une synthèse)}

L'auteur étudie l'origine du double commandement de la charité; il s'agit du jumelage de la charité fraternelle et de la charité divine dans la tradition biblique.

Bien qu'ils enseignent et l'amour de Dieu et la charité fraternelle, nulle part les écrits de l'Ancien Testament ne rapprochent explicitement l'une de l'autre ces deux commendements. Toutefois on peut déceler quelques indices qui préparent la route au rapprochement déjà formel dans le Nouveau Testament. Dans la tradition deutéronomique, les textes concernant l'amour s'apparentent à ceux de l'Alliance: l'amour de Yahweh pour les hommes s'exprime, à n'en pas douter, dans l'Alliance elle-même (voir Dt 7, 7-9). La charité envers le prochain est fondée sur la bienveillance divine (l'enseignement prophétique). Dans la tradition sapientielle, l'observation des commandements comme expression de l'amour de Dieu concerne tout homme à l'égard de Dieu. C'est l'amour de Yahweh qui procure la sagesse, et c'est l'amour de la sagesse qui attire, à coup sûr, la charité de Dieu (le texte classique: Si 4, 14).

Les écrits de Qumrân ont eux aussi la doctrine sur l'amour de Dieu, et sur l'amour envers les frères membres de la Communauté, mais ils n'associent jamais ce double aspect de la charité.

On s'est plu à renvoyer aux Testaments des XII Patriarches dans lesquels, de fait, les exhortations à la charitè occupent une place importante. On y trouve déjà les deux préceptes associés, mais la notion de charité est liée à celle de crainte de Dieu.

Quant aux écrits rabbiniques, nous voyons un certain exclusivisme: le judaïsme, historiquement parlant, a dû se défendre contre les influences du dehors, et cela tout simplement pour pouvoir rester fidèle à sa mission. En idernière analyse, la charité de l'homme reposait sur celle de Dieu dont elle est inséparable.

${ }_{55} \mathrm{O}$ wplywie tradycji deuteronomicznej na $1 \mathrm{~J}$ zob. Rennes J., La première épître de Jean, Genewa 1968. O wpływie zaś tradycji mądrościowej na pisma Janowe zolb. Ziener G., Weisheitsbuch und Johannesevangelium, „Biblica”, 38 (1957) 396-418; 39 (1958) $37-60$. 
Parmi les représentants du judaïsme hellénistique, domine Philon d'Alexandrie qui, dans son exégèse, note un lien entre les deux préceptes d'amour.

Dans le Nouveau Testament, les synoptiques placent l'association: charité fraternelle - charité divine sur les lèvres soit de Jésus lui-même (Mc 12, 28-34; Mt 22, 34-40), soit d'un docteur de la loi (Lc 10, 25-28). C'est chez Mc qu'on cherche généralement la tradition plus ancienne et authentique (Lagrange): dans ce logion, on peut faire atteindre l'ipsissima vox du Christ. Le récit de Mc - mođèle de théologie biblique - pourrait, ce semble, être examiné däns le milieu missionnaire de l'Eglise naissante. Mt est plus court que Mc, il utilise un terme de Lc ,Iegiste”. L'orientation théologique de ce récit est une parénèse du royaume des cieux; l'accent est mis par Jésus sur la charité, non pas sur la justice. Lc présente la version la plus récente; son orientation catéchétique a, au sein de la communauté, sa portée doctrinale: c'est l'histoire du salut.

Dans sa première épître, saint Jean n'a pas identifié sans plus l'amour envers Dieu et la charité entre les hommes; il a établi entre les deux amours les rapports les plus étroits, et de la façon, à n'en pas douter, la plus heureuse. L'essentiel, c'est:

- la mise en valeur de la révélation de l'amour divin pour l'homme; dans ce sens la charité de Dieu est première par rapport à celle entre soi (4, 7-12. 19). - La charité fraternelle est, par conséquent, liée organiquement à la charité divine, à tel point que la charité fraternelle et l'amour de Dieu sont de même nature. Ces deux amours sont si intimément liés que Jean les présente comme ne formant qu'un seule entité; ce ne sont plus deux amours, mais un seul, l'amour révélé $(4,21)$.

- La charité fraternelle est non seulement inséparable de l'amour de Dieu, mais elle détient même une certaine primauté pratique. C'est seulement en aimant nos frères que nous pouvons aimer Dieu. Pour aimer vraiment Dieu, il est indispensable d'aimer le prochain $(4,20)$. Jean Théologien, présente le système de charité "des vases communicants". C'est à partir d'une tradition deutéronomique (il y a entre le Deutéronome et les oeuvres de Jean des affinités de vocabulaire, de style et des points communs dans la théologie), ainsi que d'une tradition sapientielle que saint Jean a été amené à approfondir le rapport entre deux amours. 